\title{
USING STABLE ISOTOPES OF WATER TO DETERMINE CONTRIBUTION OF GLACIAL MELT TO STREAM FLOW AND PLANT WATER USE IN Grand Teton National Park
}
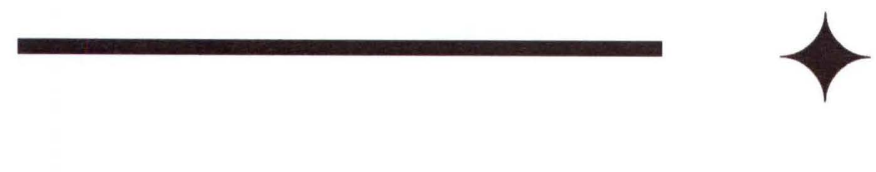

\author{
JESSICA M. CABLE \& KIONA OGLE $\uparrow$ UNIVERSITY OF WYOMING $\downarrow$ LARAMIE
}

\begin{abstract}
$\downarrow$ AbSTRACT
The loss of mountain glaciers will have a substantial impact on streamflow, and will consequently impact human and ecological systems. Grand Teton National Park is renowned for its glaciers, namely the Grand and Middle Teton glaciers, and their extent is rapidly declining. Not well understood is the contribution of glacier meltwater to streamflow and the importance of the rivers for riparian plant water use. The goals of this study were to determine the relative contribution of snowmelt and glacier meltwater to streamflow in the Middle and Grand Teton watershed, and the contribution of these watersheds to Cottonwood Creek, a tributary of the Snake River. Additionally, the contribution of river water vs unsaturated alluvial soil water to riparian plant water use was quantified. A field campaign was conducted in mid-August, 2008, where snowmelt, river, plant stem, and soil samples were collected from the Middle Teton (MT) and Grand Teton (GT) watersheds, and Cottonwood Creek. Water was extracted from the plant stems and soils. All water was analyzed for stable isotopic content $\left(\delta \mathrm{D}\right.$ and $\left.\delta^{18} \mathrm{O}\right)$. The data were analyzed with a mixing model in a Bayesian framework, which allowed for full accounting of uncertainty in the data and model. Despite a fairly large and persistent snowpack, glacier meltwater contributed nearly $92 \%$ and $79 \%$ to stream flow in the Grand and Middle Teton watersheds during this period of time. However, the range of glacier meltwater contributions was quite large because of the similar isotope values of snowmelt and glacier melt water. The MT watershed contributed $29 \%$ of the water to Cottonwood Creek and the GT watershed contributed
\end{abstract}

about $16 \%$. The remaining contribution was likely outflow from Jenny Lake. Nearly $28-55 \%$ of plant water was derived from the river, so the bulk of their water was derived from unsaturated alluvial soils. This is likely because plant roots require well-drained soils, so they do not have their roots directly in the river. These findings suggest that further decline in the Grand and Middle Teton glaciers will reduce streamflow within each watershed and streamflow in Cottonwood Creek. The latter effect may impact the Snake River, which is a major tributary of the Columbia River. Further, loss of the Grand and Middle Teton glaciers will impact riparian plant water availability, and any impact on growth may affect other species, such as birds, which are important animals for Park visitors.

\section{$\uparrow \quad$ INTRODUCTION}

Glacial recession has accelerated over the past several decades (e.g., Marston et al. 1991), which is largely attributed to climate change (Lemke et al. 2007) Continued decline of glacier mass will result in a transient increase in river discharge (Lemke et al. 2007. The impacts of glacial mass loss on the hydrology and ecology of glacial-fed montaine watersheds may be substantial. For example, glacier melt-water sustains relatively high streamflow late in the summer after the peak of snowmelt runoff (Cable et al. 2009; Rees and Collins 2006). Thus, glacial mass loss could impact the ecological activity and biodiversity of riparian ecosystems in the mid to late summer (Brown et al. 2007; Milner et al. 2001; Milner and Petts 1994). It is critical to understand variation in streamflow sources, 
such as glacier melt and snowmelt because of the potential impacts of climate change. For example, in addition to glacier recession, climate change predictions for the western U.S. are for shifts in precipitation from snow- to rainfall-dominated. Snowfall accounts for approximately 50 to $70 \%$ of total precipitation (Clark et al. 2001), so a shift to rainfall will significantly impact streamflow. Brittain and Milner (2001) concluded that glacier-fed rivers are excellent indicators of climate change because of their strong link to climate variability. The impact of glacial mass loss in National Parks, such as Grand Teton National Park, may be additionally devastating because of potential impacts on tourism and visitor enjoyment of the park's natural resources.

This study focused on the Middle Teton and Teton Glacier-fed watersheds in Grand Teton National Park. The goal of this study was to: (1) distinguish sources of streamflow by partitioning flow into that derived from glacier melt and snowmelt using naturally occurring isotopic tracers (deuterium $-\delta^{2} H$, oxygen- 18 - $\delta^{(8} \mathrm{O}$ ); and (2) determine the importance of the different streamflow sources, namely river water vs. unsaturated alluvial soil water, to contemporary riparian plant water use by using stable isotopes of water extracted from plant stems collected from plants found along the glacier-fed watersheds.

\section{$\downarrow \quad$ Methods}

Stable isotopes of water $\left(\delta^{2} \mathrm{H}\right.$ and $\left.\delta^{18} \mathrm{O}\right)$ have successfully been used as hydrologic tracers to constrain estimates of the contributions of different water sources to streamflow, including snowmelt, glacier ice, and groundwater (Behrens et al. 1971; Obradovic and Sklash 1986) (Behrens et al. 1978; Dincer et al. 1970; Martinec et al. 1974; Rodhe 1981) (Hooper and Shoemaker 1986). Although there have been a number of important hydrological investigations in Wyoming that have employed isotope tracers (Benjamin et al. 2004; Coplen and Kendall 2000; Frost et al. 2002; Frost and Toner 2004; Schuster et al. 2000), the use of isotopic tracers in studies to identify contributions of snowmelt and glacier melt to streamflow in alpine catchments has received little attention. Potential effects of climate variability, loss of alpine glaciers, and forest disturbances on streamflow are highly uncertain. Stable isotope tracers can play a prominent role in reducing this uncertainty.

Field data collection - A field campaign was conducted in mid-August, 2008, when streamflow is typically dominated by glacier melt in glacier-fed watersheds. However, snowpacks were persistent and fairly large at the time of sampling. Water was collected from high in the Middle Teton (MT) and Grand Teton (GT) watersheds, and from Cottonwood Creek, into which the MT and GT watersheds flow. All samples were collected in $20 \mathrm{~mL}$ HDPE bottles (Nalgene) and parafilmed. In the MT watershed, streamwater was collected from Garnet Creek near the base of snowfields located below the glacier and in the GT watershed, streamwater was collected from the inflow of Delta Lake and from Delta Lake itself. Sampling was focused on accessible areas. Snowmelt water was collected directly from dripping snowpacks. Water was also collected from Cottonwood Creek above and below the confluence with Glacier Creek (the tributary from the GT watershed) and Garnet Creek (the tributary from the MT watershed). At multiple locations (in the MT and GT watersheds and along Cottonwood Creek), plant stems were collected from multiple species and soil (unsaturated alluvial soil, $0-10 \mathrm{~cm}$ deep) was collected from near the base of the plants. Each plant sample was associated with a particular water sample from the creeks. Four species were sampled: Picea engelmanni, Salix spp (multiple species), Pinus contortous, and Populus spp (multiple species). Hereafter, these will be referred to as spruce, willow, pine, and cottonwood, respectively. Water was cryogenically extracted from the stems and soil, and all water samples were analyzed at the University of Wyoming Stable Isotope Facility (Los Gatos liquid water isotope analyzer, precision (sd): 0.24 and 0.22 for $\delta \mathrm{D}$ and $\left.\delta^{18} \mathrm{O}\right)$.

\section{Data analysis}

Described below is a Bayesian modeling approach (Berliner 1996; Clark 2005; Ogle 2008; Wikle 2003) for analyzing the stable isotope data. This method provides a fully consistent statistical framework for analyzing the data within the context of an isotope mixing model. The Bayesian model has three components: (1) the data model that defines the likelihood of the observed isotope data, (2) the process model that includes a mixing model and models for the fractional contributions of different source waters, and (3) the parameter model that defines the prior distributions for all model parameters and variance terms.

The first part of the data model combines the likelihoods for observed $\delta \mathrm{D}$ and $\delta^{18} \mathrm{O}$ data for the source waters. We transformed the $\delta^{18} \mathrm{O}$ values by multiplying all the data by 7 to attain similar variation between the $\delta \mathrm{D}$ and transformed $\delta^{18} \mathrm{O}$ data. This 
transformation does not affect the mass-balance assumptions associated with the mixing model. The equations below are for snow and glacier source waters for Glacier Creek and Garnet Creek. We assume the isotope data $\left(\delta \mathrm{D}, \delta^{18} \mathrm{O}\right.$, eqn [1]) from the two water sources come from a multivariate normal distribution (MNormal in eqn [1]) with a mean vector $(\mu)$ and precision covariance matrix $(\Omega)$. The multivariate normal accounts for potential correlations between the measured $\delta \mathrm{D}$ and $\delta^{18} \mathrm{O}$ data and partially captures the temporal variability in the end members. For observation $j\left(j=1,2, \ldots, N_{s r c}\right)$ associated with source src:

$$
\left[\begin{array}{l}
\delta \mathrm{D}_{s r c} \\
\delta^{18} \mathrm{O}_{s r c}
\end{array}\right]_{\{j\}} \sim \text { MNormal }\left(\left[\begin{array}{l}
\mu \delta \mathrm{D}_{s r c} \\
\mu \delta^{18} \mathrm{O}_{s r c}
\end{array}\right], \Omega_{s r c}\right)
$$

The means $(\mu$ 's) for glacier $(\operatorname{src}=g)$ and snow $(s r c=s)$ source waters are assigned non-informative (diffuse), independent normal priors, and the precision matrices for the two sources are given by relatively noninformative Wishart priors, a multivariate version of the gamma distribution that is commonly used as a prior for precision matrices (Gelman et al. 2004). Thus, the priors are:

$$
\begin{array}{rlr}
\mu \delta \mathrm{D}_{s r c}, \mu \delta^{18} \mathrm{O}_{s r} & \sim \text { Normal } 0,0.00001 & s r c=g, s \\
\Omega_{s r c} & \sim \text { Wishart } \mathrm{R}, 2 & s r c=g, s
\end{array}
$$

Note that $\mathrm{R}$ in Eqn (2) is the $2 \times 2$ identity matrix, and the "2" represents the minimum "degrees of freedom," thus, this parameterization gives the most non-informative prior for $\Omega_{s r c}$.

The second part of the data model defines the likelihood of the stream isotope data. Similar to the model for the source isotope data, we assume that the stream (Glacier Creek and Garnet Creek) isotope data follow a bivariate normal distribution with a mean $(\mu)$ and a covariance matrix $\left(\Omega_{\text {stream }}\right)$. Thus, for stream observation $i$ associated with sampling period $t$ and location $d$ :

$$
\left[\begin{array}{l}
\delta \mathrm{D}_{\text {stream }} \\
\delta^{18} \mathrm{O}_{\text {stream }}
\end{array}\right]_{\{i\}} \sim \text { MNormal }\left(\left[\begin{array}{l}
\mu \delta \mathrm{D}_{\text {stream }} \\
\mu \delta^{18} \mathrm{O}_{\text {stream }}
\end{array}\right]_{\{t, d\}}, \Omega_{\text {stream }}\right)
$$

The mean stable isotope values for the stream are given by a mixing model, which defines the mean values as the sum of the fractional contribution $(p)$ of each source multiplied by each source's expected isotope signature (i.e., the $\mu$ 's in eqns 1 and 3):

$$
\left[\begin{array}{l}
\mu \delta \mathrm{D}_{\text {stream }} \\
\mu \delta^{18} \mathrm{O}_{\text {stream }}
\end{array}\right]=\sum_{s r c=g, s} p_{\left.s r c_{\{t, d\}}\right\}} \cdot\left(\begin{array}{l}
\mu \delta \mathrm{D}_{s r c} \\
\mu \delta^{18} \mathrm{O}_{s r c}
\end{array}\right)
$$

To satisfy the mass-balance constraints $0 \leq p_{\text {src }}$ $\leq 1$ and $p_{g}+p_{s}=1$, we modeled the vector of two $p$ 's by back-transforming a logit function with parameter vector $u$, where $u$ had a uniform prior between 0 and 0.4 .

$$
\begin{aligned}
& p_{s r c}=\frac{e^{u_{s r c}}}{\left(1+e^{u_{s r c}}\right)} \\
& u \sim U(0,0.4)
\end{aligned}
$$

The same model was implemented for Cottonwood Creek and the plant stem samples. Cottonwood Creek had three sources (Glacier Creek, Garnet Creek, and "other"- which was the upstream source) and the stem model has two sources (soil water and river water). For Cottonwood Creek, the "other" watershed source is the water sample collected above the Glacier Creek confluence, as this water is likely primarily from Jenny Lake. We implemented the models in WinBUGS, a free software package for implementing Bayesian data analyses (Lunn et al. 2000). Using WinBUGS, we ran two parallel MCMC (Markov chain Monte Carlo) chains for 20,000 iterations, and we thinned every 10 to reduce within chain autocorrelation. We discarded the first 5,000 samples as a burn-in period (prior to convergence of the chains), resulting in a total of 3,000 samples for calculating the posterior statistics.

\section{RESULTS}

The mean temperature and precipitation in August 2008 was $10.3^{\circ} \mathrm{C}$ [min and max: -0.28 and 21] and $3.10 \mathrm{~cm}$, and cumulative snowfall from October 2007 through August 2008 was 4.9m (NCDC 2009). This was nearly twice as much snow compared to the prior year (2006 to 2007), which was $2.9 \mathrm{~m}$ (NCDC 2009). The large amount of snow in 2007-2008 resulted in a persistent snowpack in August 2008 during the field campaign (personal observation).

Glacier water in streams within GT and MT watersheds - The mean [+/- standard error] isotope value of water from Garnet Creek in the MT watershed was $-133.6 \%$ [ $[+/-0.16]$ and $-18.0 \%$ o $[+/-0.05]$, and the mean stream sample from Glacier Creek and Delta Lake 
in the GT watershed was $137.6 \%$ [ $+/-0.44]$ and $18.5 \%$ o [+/- 0.14]. To better capture the spatial variability associated with snowmelt isotope values, snowmelt data from both watersheds were pooled in the analysis. The model-estimated mean $[95 \%$ credible interval] snowmelt isotope values were $-126.3 \%$ [$130.6,-122.2]$ and $-16.8 \%$ o $[-17.5,-16.2]$. The glaciers in each watershed were inaccessible, so the mean glacier value from a neighboring watershed were incorporated into the analysis $(-134.5 \%$ [ $[-136.9$, 132.2], -18.2\%o [-18.6, -17.9], Dinwoody Glacier, Cable et al. 2009). Assuming baseflow was minimal in the GT and MT watersheds, the proportional contributions of glacier meltwater were $91.5 \%$ [63.0, $99.4 \%]$ and $78.6 \%[45.8,97.0]$, respectively (Figure 1). Snowmelt water comprised $8.5 \%[0.6,37.2]$ and $21.4 \%$ $[3.0,54.2]$ of streamflow in the GT and MT watersheds, respectively. The similar isotope values of glacier and snowmelt resulted in the large credible intervals.

Contribution of water from MT and GT watersheds to Cottonwood Creek - Near the confluence with Taggart Lake outflow creek, below the confluence with both Garnet and Glacier Creeks, Cottonwood Creek was comprised of $29.0 \%$ [2.5, 71.9] water from Garnet Creek, 16.2\% [1.7, 40.1] from Glacier Creek, and 54.8\% [17.7, 82.2] from upstream sources (likely from Jenny Lake) (Figure 2).

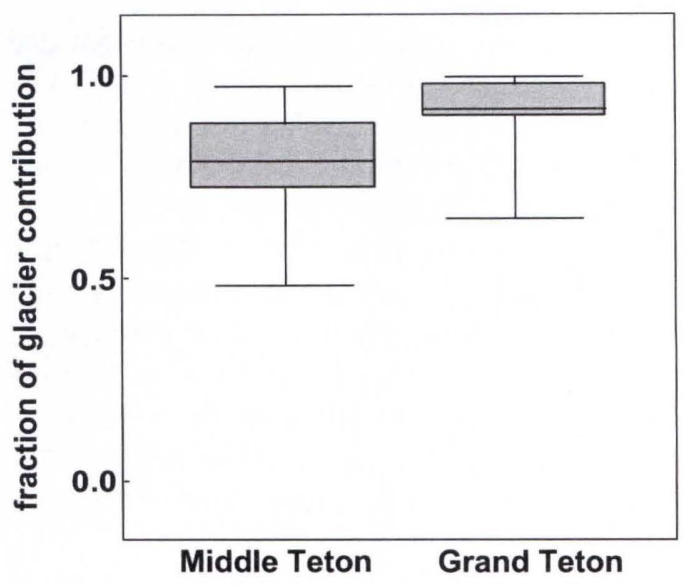

Figure 1. The fractional contribution of glacier water to streamflow in Garnet Creek and Glacier Creek in the Middle and Grand Teton watersheds, respectively. The means are presented with $95 \%$ credible intervals. The remaining fraction of water contribution is from snowmelt water (glacier + snowmelt $=1$ ).

River water use by four plant species - The four plant species (or species groups) differed in their use of river-derived vs. unsaturated alluvial soil water. The willow species, which was sampled within the GT and MT watersheds, derived 38.6\% [9.2, 70.1] of their water from the river. Spruce and pine were sampled within each watershed and along Cottonwood Creek, and they derived $53.0 \%[21.0,82.7]$ and $54.9 \%$ [14.1, $90.2]$ of their water from the river(s), respectively. The variety of cottonwood species sampled only along Cottonwood Creek derived nearly $28.7 \%[3.7,68.8]$ of their water from the river (Figure 3).
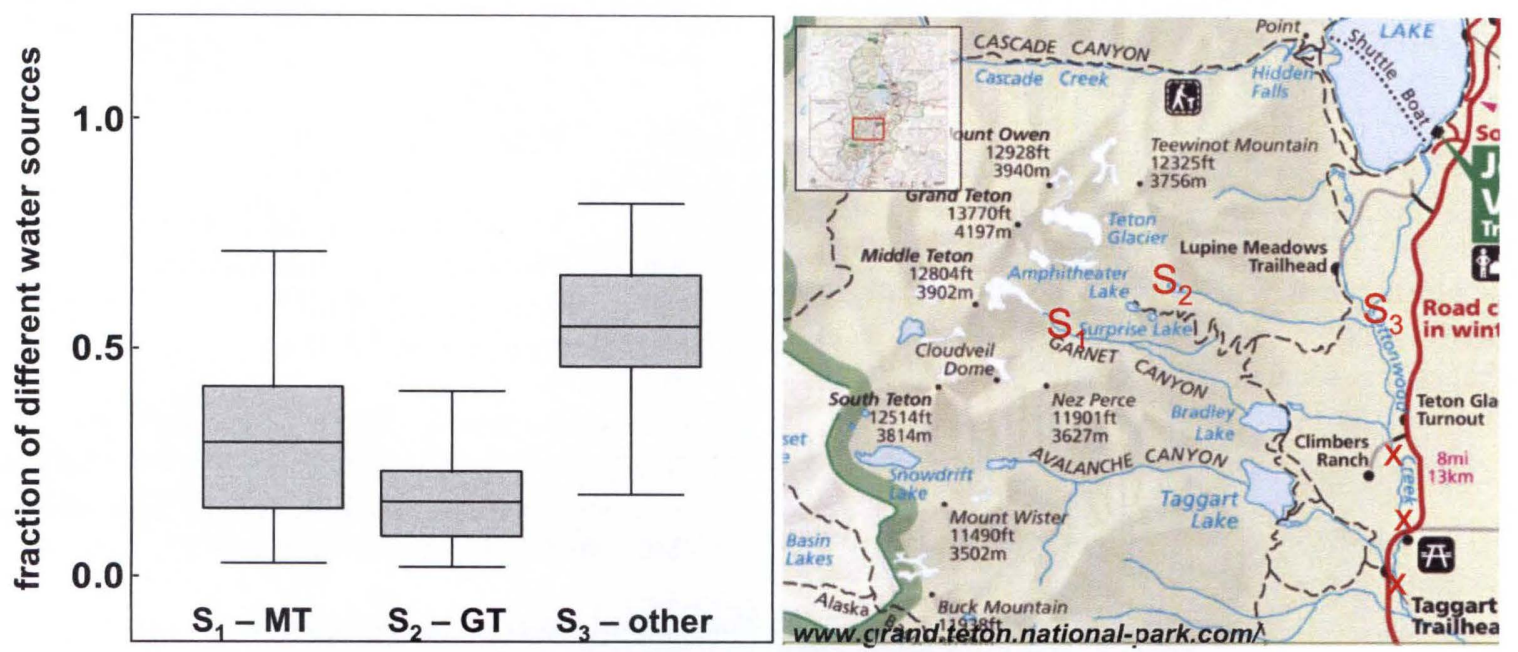

Figure 2. (left panel) The fractional contribution of water from the Middle Teton (MT), Grand Teton (GT), and "other" water sources to Cottonwood Creek. (right panel) The S's denote the sampling location for the three sources, where S1 is near the Middle Teton Glacier from Garnet Creek, S2 is from Delta lake in the Grand Teton watershed, and S3 refers to the "other" water source. This source is likely from Jenny Lake and was sampled above the confluence of Glacier Creek (GT watershed) and Cottonwood Creek. 


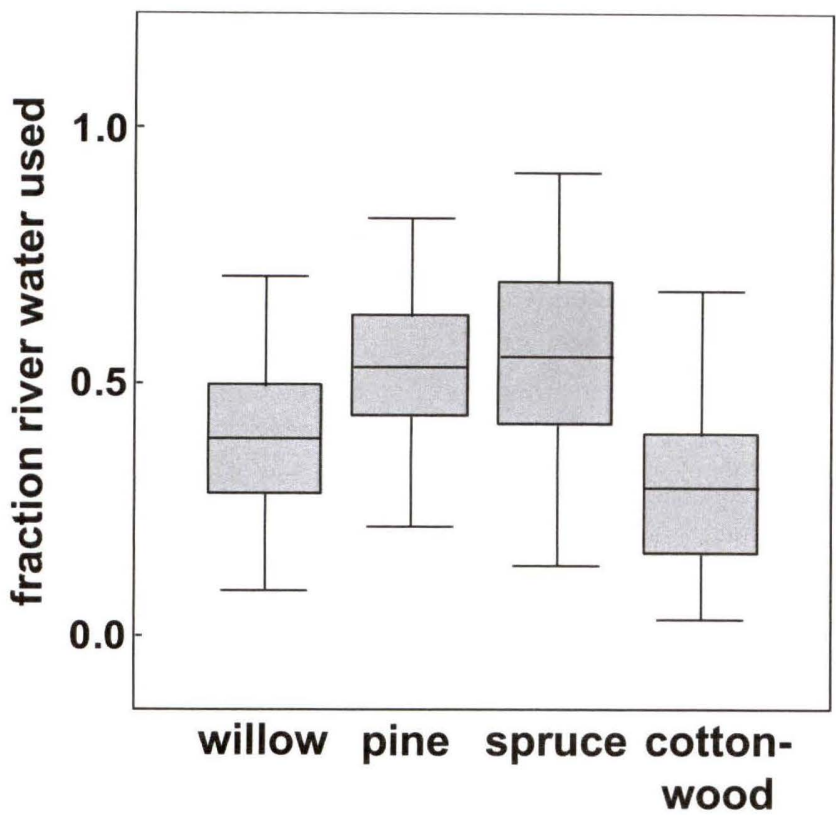

Figure 3. The relative uptake of river water (vs unsaturated alluvial soil water) by four plant species or species groups. The "willow" refers to multiple species, "pine" is limberpine, "spruce" is Engelmann's spruce, and "cottonwood" also refers to several species, including aspen.

\section{$\downarrow$ Discussion}

The prevalence of glaciers in Grand Teton National Park draws tourists and is significant for streamflow and plant water use. In this study, the fractional contribution of glacier melt water and snowmelt water in the Middle Teton and Grand Teton watersheds was quantified in August, 2008, when snowpack should have been at a minimum. Also quantified was the contribution of water from the Middle Teton and Grand Teton watersheds to streamflow in Cottonwood Creek, which flows into the Snake River, and the amount of river water vs. soil water used by common riparian plants.

Despite a fairly persistent snowpack (personal observation), glacier meltwater contributed nearly $92 \%$ and $79 \%$ to stream flow in the Grand and Middle Teton watersheds during this period of time. However, the range of glacier meltwater contributions was quite large because of the similar isotope values of snowmelt and glacier melt water. Cable et al. (2009) found that glacier melt water was a large proportion of streamflow in low-flow years $(59 \%)$ or early and late in the summer period $(69 \%, 53 \%)$. The Middle Teton watershed contributed $29 \%$ of the water to Cottonwood Creek and the Grand Teton watershed contributed about $16 \%$. The remaining contribution was likely outflow from Jenny
Lake. Nearly $28-55 \%$ of plant water was derived the river, so the bulk of their water was derived from unsaturated alluvial soils. This is likely because plant roots require well-drained soils, so they do not have their roots directly in the river. Others have found that riparian plants often do not solely rely on stream water (Smith et al. 1998) but there is a great deal of species variation (Snyder and Williams 2000), which was observed in this study.

These findings suggest that further decline in the Grand and Middle Teton glaciers will greatly reduce streamflow within each watershed and streamflow in Cottonwood Creek. The latter effect may impact the Snake River, which is a major tributary of the Columbia River (Kammerer 1990). Further, loss of the Grand and Middle Teton glaciers will impact riparian plant water availability, and any impact on growth may affect other species, such as birds (e.g., GTNP bird guide), which are important animals for Park visitors. Some caveats of this study are that intra-seasonal and inter-annual variation in snowmelt and glacier melt water contributions were not captured, which is important for partitioning these sources of streamflow (Cable et al. 2009). Also, the glacier isotope values were derived from a nearby but separate watershed (Dinwoody Glacier in the Wind River Range), and the isotope values of GT and MT glaciers may differ from Dinwoody Glacier. Lastly, rain and baseflow were not incorporated into the analysis because it did not rain during the field campaign. Baseflow samples were not collected because this must occur when snowmelt and glacier melt are at a minimum (winter). However, this study shows the potential for glacier melt to have a significant role in the surface hydrology and riparian plant communities of Grand Teton National Park.

\section{$\uparrow \quad$ Literature Cited}

Behrens, H., H. Bergmann, H. Moser, W. Rauert, W. Stichler, W. Ambach, H. Eisner and K. Pessl. 1971. Study of the discharge of Alpine glaciers by means of environmental isotopes and dye tracers. Z. Gletscherkd. Glazialgeol. 7:79-102.

Behrens, H., H. Moser, H. Oerter, W. Rauert and W. Stichler. 1978. Models for the runoff from a glaciated catchment area using measurements of environmental isotope contents. In International Symposium on Isotope Hydrology. (International Atomic Energy Agency, Vienna). pp 829-846. 
Benjamin, L, L.L Knobel, L.D. Hall, L.D. Cecil and J.R. Green. 2004. Development of a local meteoric water line for southeastern Idaho, western Wyoming, and south-central Montana. USGS, ed. (USGS). pp 17.

Berliner, M. 1996. Hierarchical Bayesian time series models. In: Maximum Entropy and Bayesian Methods. Hanson K, Silver R, (eds). Kluwer, Norwell, MA. pp 15-22.

Brittain, J.E., A.M. Milner. 2001. Ecology of glacierfed rivers: current status and concepts. Freshwater Biology 46:1571-1578.

Brown, L.E., D.M. Hannah and A.M. Milner. 2007. Vulnerability of alpine stream biodiversity to shrinking glaciers and snowpacks. Global Change Biology 13:958-966.

Cable, J.M., K. Ogle and D.W. Williams. 2009. Application of a Bayesian mixing model to determine the contribution of glacier melt to streamflow in the Wind River Range, Wyoming. Hydrological Processes in review.

Clark, J.S. 2005. Why environmental scientists are becoming Bayesians. Ecology Letters 8:2-14.

Clark, M.P., M.C. Serreze and G.J. McCabe. 2001. Historical effects of El Nino and La Nina events on the seasonal evolution of the montane snowpack in the Columbia and Colorado River Basins. Water Resources Research 37:741-757.

Coplen, T.B. and C. Kendall. 2000. Stable hydrogen isotope and oxygen isotope ratios for selected sites of the U.S. Geological Survey's NASQAN and Benchmark surface-water networks. USGS, ed. pp 1-409.

Dincer, T., B.R. Payne, T. Florkowski, J. Martinec, E. Tongiorgi. 1970. Snowmelt runoff from measurements of tritium and oxygen- 18 . Water Resources Research 6:110-124.

Frost, C.D., B.N. Pearson, K.M. Ogle, E.L. Heffern, and R.M. Lyman. 2002. Sr isotope tracing of aquifer interactions in an area of accelerating coal-bed methane production, Powder River Basin, Wyoming. Geology 30:923-926.
Frost, C.D. and R.N. Toner. 2004. Strontium isotopic identification of water-rock interaction and ground water mixing. Ground Water 42:418432.

Gelman, A., J.B. Carlin, H.S. Stern and D.B. Rubin. 2004. Bayesian Data Analysis. (Chapmal \& Hall/CRC, Boca Raton).

Hooper, R.P. and C.A. Shoemaker. 1986. A Comparison of Chemical and Isotopic Hydrograph Separation. Water Resources Research 22:1444-1454.

Kammerer, J.C. 1990. Largest Rivers in the United States. USGS, ed.

Lemke P., J. Ren, R.B. Alley, I. Allison, J.J. Carrasco, G. Flato, Y. Fujii, G. Kaser, P. Mote, R.H. Thomas and T. Zhang T. 2007. Observations: Change in Snow, Ice and Frozen Ground. In: Climate Change 2007: The Physical Science Basis. Contribution of Working Group I to the Fourth Assessment Report of the Intergovernmental Panel on Climate Change Solomon S. QD, Manning M., Chen Z., Marquis M., Averyt K.B., Tignor M., Miller H.L.(eds.). Cambridge University Press Cambridge, United Kingdom and New York, NY, USA.

Lunn, D.J., A. Thomas, N. Best and D.J. Spiegelhalter 2000. WinBUGS - A Bayesian modelling framework: Concepts, structure, and extensibility. Statistics and Computing $10: 325-337$.

Martinec, J., U. Siegenthaler, H. Oseschger and E. Tongiorgi. 1974. New insights into the run-off mechanism by environmental isotopes. (IAEA, Vienna). pp 129-149.

Milner, A.M., J.E. Brittain, E. Castella and G.E. Petts. 2001. Trends of macroinvertebrate community structure in glacier-fed rivers in relation to environmental conditions: a synthesis. Freshwater Biology 46:1833-1847.

Milner, A.M. and G.E. Petts. 1994. Glacial Rivers Physical Habitat and Ecology. Freshwater Biology 32:295-307.

NCDC. 2009. http://www.ncdc.noaa.gov/oa/ncdc.html. (National Oceanic and Atmospheric Association, Asheville, NC. 
Obradovic, M.M. and M.G. Sklash. 1986. An Isotopic and Geochemical Study of Snowmelt Runoff in a Small Arctic Watershed. Hydrological Processes 1:15-30.

Ogle, K. 2008. Hierarchical Bayesian statistics: Merging experimental and modeling approaches in ecology. . Ecological Applications In press.

Rees, H.G. and D.N. Collins. 2006. Regional differences in response of flow in glacier-fed Himalayan rivers to climatic warming. Hydrological Processes 20:2157-2169.

Rodhe, A. 1981. Spring Flood Meltwater or Groundwater. Nordic Hydrology 12:21-30.

Schuster, P.F., D.E. White, D.L. Naftz and L.D. Cecil. 2000. Chronological refinement of an ice core record at Upper Fremont Glacier in south central North America. Journal of Geophysical Research-Atmospheres 105:4657-4666.
Smith, S.D., D.A. Devitt, A. Sala, J.R. Cleverly and D.E. Busch. 1998. Water relations of riparian plants from warm desert regions. Wetlands:18:687-696.

Snyder, K.A. and D.G. Williams. 2000. Water sources used by riparian trees varies among stream types on the San Pedro River, Arizona. Agricultural and Forest Meteorology 105:227240.

Wikle, C.K. 2003. Hierarchical Bayesian models for predicting the spread of ecological processes. Ecology 84:1382-1394. 